\title{
A HISTORY OF THE STEREOLOGY IN CHINA
}

\author{
Li WANG ${ }^{1}$, YONG TANG ${ }^{2}$, KeJUN KANG $^{3}$, ZHIQIANG CHEN $^{3}$, RUIYUN PENG ${ }^{4}$, \\ ZHENGWEI YANG ${ }^{5}$, GUOQUAN LIU ${ }^{凶, 6}$
}

${ }^{1}$ Institute of Scientific and Technical Information of China, Beijing, 100038 China; ${ }^{2}$ Department of Histology and Embryology, Chongqing Medical University, Chongqing, 400016, China; ${ }^{3}$ Department of Engineering Physics, Tsinghua University, Beijing 100084, China; ${ }^{4}$ Institute of Radiation Medicine, Academy of Military Medicine Sciences, Beijing, 100850, China; ${ }^{5}$ Morphometric Research Laboratory, North Sichuan Medical College, Nanchong, 637000, China; ${ }^{6}$ University of Science and Technology Beijing, Beijing, 100038, China e-mail: tscss@mail.tsinghua.edu.cn; ytang062@163.com; kkj-dep@mail.tsinghua.edu.cn; czq@mail.tsinghua.edu.cn; pengry@bmi.ac.cn; zwyang_nsmc@163.com; g.liu@ustb.edu.cn (Received June 16, 2017; revised December 8, 2017; accepted February 2, 2018)

\begin{abstract}
This review article introduces the formation and development of stereology in China under the background of the development of international stereology. In the early 1970s, some stereological monographs and collections were introduced into China, and Chinese scholars began to understand, study and promote stereology knowledge. Meanwhile, the widespread use of image analysis systems has contributed to the spread of stereology in China. On the other hand, academic exchanges and personnel training have played a catalytic role in the formation of stereology in China. According to China National Knowledge Infrastructure (CNKI) statistics, the number and impact of Chinese papers in stereology continues to grow during the past 30 years. After in-depth discussion, Chinese scholars have adopted a broader definition of stereology. With economic development and technological progress, China has great potential to develop, promote and apply the stereological methods and the related technologies.
\end{abstract}

Keywords: biomedical stereology, China, history, image analysis, materials stereology, stereology.

\section{INTRODUCTION}

In 1961, the term "stereology", which is the study of three-dimensional objects using 0-, 1-, 2-, and 3-dimensional probes with 1-, 2-, or 3-dimensional samples to obtain structural data about the 3-dimensional objects of interest, was created by a group of experts in the fields of Biology, Geology, Engineering, and Materials at a small meeting that was organized by Hans Elias. In 1962, the International Society for Stereology was set up, and the first International Congress of Stereology ( $1^{\text {th }}$ ICS) was held in Vienna, Austria. Microscopic technology was widely used in China in the 1950s. After more than 10 years development and innovation of the microscopic technology, high-resolution optical microscope and electron microscope were widely used, and the microscopic technology was combined with the computer technology to form an automatic image analysis system that has greatly promoted the development and application of stereology. Being driven by the International Society for Stereology, the academic exchanges in the field of stereology have become increasingly frequent, and the monographs and collected works of the stereology have been widely disseminated.

In China, the most populations in the world, stereology has also been flourishing, and it has obtained a quite wide range of popularization and applications. Chinese Society for Stereology (CSS) was approved by the Chinese government in 1987, and the current members of the CSS are more than 1,500. In 1996, the CSS founded its official academic journal entitled "Chinese Journal of Stereology and Image Analysis" that has continuously published 88 issues until the end of 2017. Many universities in China have set up the related experimental courses such as stereology, quantitative metallography and image analysis, etc. There are thirty of national standards of the People's Republic of China and professional standards that have used stereology, quantitative metallography, metrological morphology and image analysis as the important analytical tools. These standards are widely used in scientific research, education and industrial production. It should be say that China may has the largest populations in the world that have applied for the stereology and the related technologies. 
This paper briefly reviews the process of the start, development and application of stereology and related technologies in China.

\section{THE BIRTH AND RISE OF THE STEREOLOGY DISCIPLINE IN CHINA}

Before the word "stereology" came into being in 1961, whether in the world or in China, to better understand three-dimensional objects, people had long explored the way to infer the geometric information of higher dimensional world from lower dimension information. Ancient Greeks and ancient Egyptians were seeking ways to determine the volume of objects. The word "Stereos" created by the Greeks was devoted to indicate "objects, solid body, three-dimensions". In the east of the world, the son of ancient Chinese mathematician $\mathrm{Zu}$ Chongzhi (A.D. $429 \sim 500$ ) proposed "Since areas can be superimposed into volume, if 'mi-shi' are the same, the volumes cannot be different" in the process of calculating the sphere volume (Wei, 1959). The expression of this in modern mathematical language is that "Since volume can be seen as superimposed by areas, when the two cubes between two parallel planes are truncated by any plane parallel to these two planes, if the two cross-sectional areas of the two cubes are always equal, the volumes of these two cubes must be equal". The essence of this was that the link between two-dimensional observation and three-dimensional characteristic feature was already established.

Since the 1960s, the dissemination of stereological knowledge in the world and the application of image analysis system in many fields promoted the start and development of the stereology in China. In the early 1970s, some monographs about stereology were introduced into China, and Chinese scholars began to know, study and generalize stereological knowledge. At the same time, the introduction and extensive application of image analysis equipments further facilitated the spreading and application of the stereological knowledge.

\section{COMPILATION OF STEREOLOGY LITERATURE}

After the concept of stereology entered China, as an important means to learn the knowledge of stereology, the compilation of foreign stereology books and collections were emphasized. The spread of stereology knowledge was originally extended from materials science, and then in biomedicine and other fields.

"Quantitative Stereology" edited by Underwood (1970) was probably the first book to bring "stereology" into China. Then in 1974, Professor Yongning
$\mathrm{Yu}$ in the Department of Materials of the University of Science and Technology Beijing (formerly Beijing Institute of Iron and Steel Technology) edited the first Chinese stereological lecture materials called "quantitative metallography". In 1980, Huilin Sun and Jishe $\mathrm{Ma}$ in Shaanxi College of Mechanical Engineering translated and published "stereology and quantitative metallography" that was originally co-authored by Pellissier and Purdy (1972). In the second half of 1987, the Chinese Society for Stereology hosted an occasional member publication material -"stereological communication". In 1988, the Chinese Society for Stereology edited "Stereology literature translation collections" (Fig. 1).

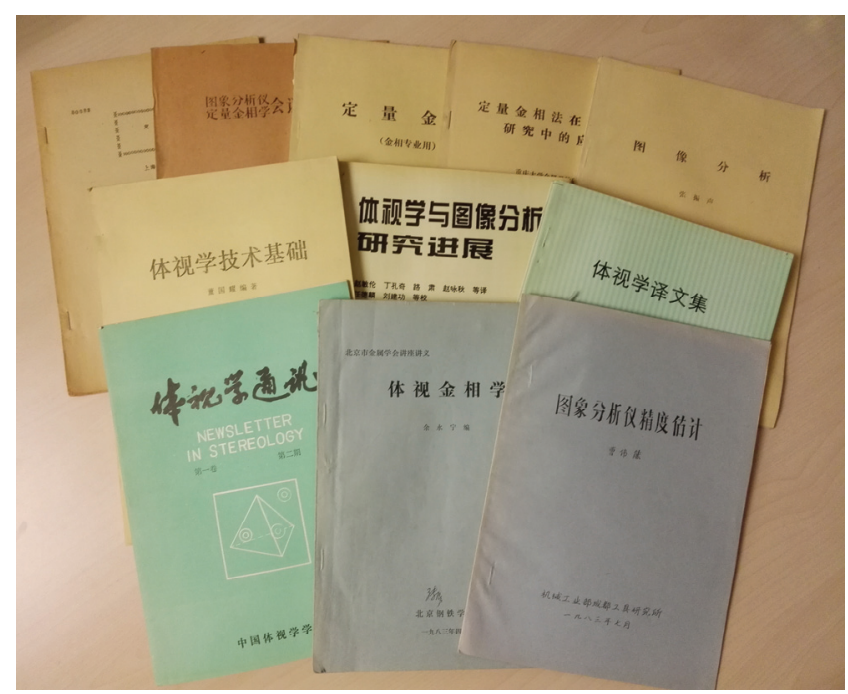

Fig. 1. The early Chinese stereological publication collections.

\section{EXCHANGE OF THE STEREOLOGICAL KNOWLEDGE}

The stereological methods have been widely used in the field of materials, which has attracted the attention of people engaging in image analysis. On the initiative of the scientific scholars in the fields of materials stereology and image analysis, Chinese scholars held the " 1 st Image Analysis, Quantitative Metallography Academic Exchange Meeting" in Chengdu, Sichuan, P. R. China in November, 1981. At the meeting, a preparatory team was proposed by the experts in meeting, and this team would be responsible for the establishment of the Chinese Society for Stereology. In August 1982, "The $2^{\text {nd }}$ Image Analyzer and Quantitative Metallography Symposium" was held in Leshan, Sichuan, P. R. China. 112 experts and scholars from 67 research institutions and enterprises participated in the symposium. In the symposium, the participants proposed to establish the editorial board to be responsible for the publishment of the collected literature of stereology. In 1983, "The $3^{\text {rd }}$ Image Analyzer and 
Quantitative Metallography Symposium" was held in Guanxian, Sichuan, P. R. China. More than 200 experts and scholars attended the symposium. The popularity and improvement of the stereological knowledge in the China soon appeared after the three early academic exchange meetings on the stereological fields.

\section{WIDE APPLICATION OF IMAGE ANALYSIS SYSTEM}

The formation of the image analysis technology in the 1950s has not only promoted the development of stereology but also directly contributed to the advent of the image analyzer in 1960s (Zhao, 1996). The advent of the image analyzer made it easy that stereology can be practically applied. The stereological theories and methods connected the two-dimensional measurement results obtained from the image analyzer to the three-dimensional structure of the studied object. The stereological theories and methods also extended the earliest application of the image analyzer in materials science to more fields (Zhang, 1978). In 1970s, the image analyzer entered China, and the extensive application of image analyzer further promoted the spread of stereology in China. According to the statistics of CNKI(China National Knowledge Infrastructure, http://www.cnki.net/) in China, the number of Chinese literature related to image analysis has increased from 1 in 1974 cumulatively reached about 1009 by 1990 . The applications of image analysis system include materials (Yin et al., 1986; Li, 1990), medicine (Zhang et al., 1989), biology (Wu et al., 1980; Yang et al., 1990), mining (Ouyang et al., 1984), agriculture (Yao et al., 1990), geology (Ren et al., 1985), remote sensing (Zhi, 1989) and so on.

\section{THE FORMATION OF THE STEREOLOGY DISCIPLINE IN CHINA}

The stereology in China was originated in 1970s, which was developed from the spreading of the foreign stereological theories and methods and the introduction and improvement of automatic metallographic image analyzer. In 1980s, image analysis methods were used in biomedicine and other research fields, which enriched the research and application fields of stereology, gradually formed the mechanism that the stereology personnel training was driven by the academic exchanges, opened up the international academic exchange, organized the academic community, and set up the professional journal and web sites.

\section{THE PROFESSIONALS TRAINING OF STEREOLOGY IN CHINA}

The cultivation modes of stereology personnel teams in China was mainly based on the following four aspects. First aspect was academic communication and training seminars, and the second aspect was to set up stereological courses in colleges and universities. The third aspect was to send persons to study abroad. The fourth aspect was to invite foreign specialists to give lectures in China.

The two main methods of early stereological personnel training were the communication and discussions of stereology, and the training course of stereology. Since the 1980s, the national and local academic exchanges and the stereological technique training courses in fundamental stereology, materials stereology, and biomedical stereology have sprung up. Some classes were authorized by the Ministry of Education of the People's Republic of China, and some were listed in the national continuing medical education projects.

On the three annual conferences of "Image Analyzer and Quantitative Metallography" held in China from 1981 to 1983 , the organizers invited the specialists to systematically teach stereology in thematic forms besides the academic communication. During the next decade, the mode of combining academic communication with stereology training seminars became an important means in early stereological personnel training. The 1980 s to the 1990 s was the most prosperous period for China to hold the stereology training courses. Numbers of the stereology training courses were held in various places, for example, "Training course of image analysis technology and its application in biomedicine", "Stereological metallography courses", "Image analysis and stereology training courses". All these courses have trained a great deal of the stereology personnel in China.

In 1974, Professor Yongning Yu held the first course of "Quantitative Metallography" at the Beijing Institute of Iron and Steel Technology (now the University of Science and Technology Beijing). This was the first time for Chinese universities to offer the specialized course of stereology. At present, Quantitative Metallography has become the required course content for the undergraduates in materials major of China's universities. In the $21^{\text {st }}$ century, some medical universities and research institutes held the biostereology course for the postgraduate students in order to systematically teach the biostereological knowledges. 
In 1978, China implemented the policy of reform and opening. Since then, some Chinese scholars lucked to have opportunities to learn from the international stereologists. For instance, Guoquan Liu (1981 1984) went to Florida, USA and studied for his doctor's degree with Professor F. N. Rhines who was one of the founders of International Society for Stereology (ISS), and at the same time worked with Professor R. T. DeHoff at University of Florida (Gainesville). Zhengwei Yang (1988 1989) studied with Professor Nigel Wreford, in the Department of Anatomy in Monash University, Australia, who was the vice president of the ISS at that time. Meiqiang Wang (1993.6 1994.6) went to Denmark Technical University to carry out the cooperation research. Yong Tang (1994 1998) studied for his doctor's degree with Professor H. J. G. Gundersen in Aarhus University, Denmark. They all have played important roles in training stereology personnel in materials science and biomedicine science after returning back to China.

It is an important means for the stereology personnel training in China to invite the international renowned stereologists to give lectures in China. Some international stereology experts who have been invited to give lectures in China included (not exclusive): Professor H. J. G. Gundersen from Denmark (1991, 1992, 1994), Professor N. G. Wreford from Australia (1991, 1998), Professor L. M. Cruz Orive from Switzerland (1992), Professor T. M. Mayhew from the United Kingdom (1992), Professor K. C. Moore, senior investigator J. M. Basgen and Professor J. C. Kinnamon (1995), Professor Arun M. Gokhale (2010, 2011) from the United States, Professor T. Takahashi $(1995,1997)$ from Japan, and so on (Fig. 2).

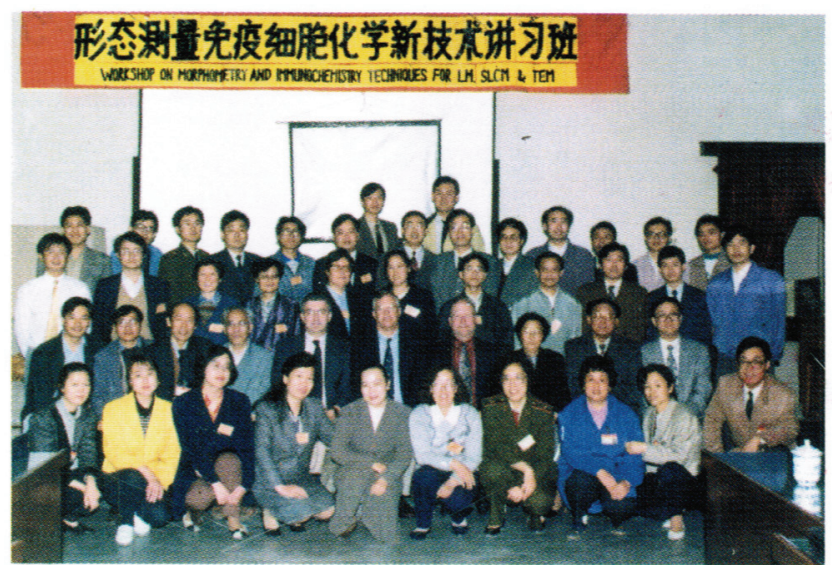

Fig. 2. Three American experts came to China to give stereology lectures in 1995.

\section{INTERNATIONAL ACADEMIC COMMUNICATION}

In 1983, two Chinese scholars Guoquan Liu and Tianhui Lin attended the Sixth International Congress for Stereology $\left(6^{\text {th }}\right.$ ICS) held at University of Florida (UF), Gainesville, USA. At that time, Liu was a Chinese visiting scholar studying for his doctorate degree under the guidance of Professor F. N. Rhines and concurrently served as an adjunct assistant professor of UF, who helped the congress president Professor R.T. DeHoff to undertake the routine work of the meeting. Mr. Tianhui Lin was a scholar from Shanghai, China, who presented 1 poster paper at the meeting, which was probably the first paper from China presented in the ICS series meeting. At the $6^{\text {th }}$ ICS, Professor Guoquan Liu lucked to meet a group of internationally renowned scholars, including Professor H.E. Exner who was then the ISS president, Professor E.E. Underwood who was the formerly ISS president, and Professor J.L. Chermant who was selected as the ISS president in later years, and many others. This was the first time for Chinese scholars to participate in the international stereological academic meetings, also the earliest contact between China scholars and the ISS. Since then, China scholars began to participate in international stereology exchanges, and Meiqiang Wang, Guoquan Liu, Yongqiu Zhao, Zhengwei Yang and other Chinese scholars personally joined the ISS. The Chinese scholars and the ISS have formed a good interaction, and academic exchanges and cooperation have been gradually expanded.

After that, many Chinese scholars successively attended "The $7^{\text {th }}$ International Congress for Stereology $\left(7^{\text {th }}\right.$ ICS)" held in the city of Caen, Caen University, France, in September 1987, "The $8^{\text {th }}$ International Congress for Stereology ( $8^{\text {th }}$ ICS) " held in the United States, in August 1991, and "The $11^{\text {th }}$ International Congress of stereology ( $11^{\text {th }}$ ICS)" held in Melbourne, Australia. At the $8^{\text {th }}$ ICS in 1991, Guoquan Liu was invited to make the Invited Theme Lecture "Recent developments in applying stereology to materials science", in which he first proposed the problem of "inverse stereology" (Liu, 1992). At the $11^{\text {th }}$ ICS, the CSS has made its first application to the ISS that the CSS would very much like to host International Congress for Stereology (ICS) in China.

In 1989, the materials and image analysis specialized committee of the CSS officially joined the ISS as a group member in the name of "Chinese Materials 
and Image Technology Group (Chinese MIT Group)". Later, Professor Guoquan Liu served continually as the Chinese representative in the ISS for 22 years (ISS Regional Representative, 1990-2011), and elected as the vice president of the ISS (2004-2007). Later, Professor Yong Tang has been elected the vice president for two consecutive terms since 2008 .

In October 2000, the CSS held the "International Academic Conference on CT and 3D imaging" in Beijing. At that time, the then ISS president, Professor J. F. Bertram, and the then secretary general of the ISS, Dr. N. Wreford, attended the conference, and Professor Bertram was invited to give a special lecture. In November 2003, the CSS hosted a satellite symposium of the $11^{\text {th }}$ ICS - "The $11^{\text {th }}$ International Congress for Stereology Beijing Conference". Professor H. E. Exner and Professor. M. Jeulin, both formerly presidents of the ISS, and the secretary general of the ISS, Dr. Wreford, and the then Editor-in-Chief of Image Analysis and Stereology, Dr. Eržen Ida, attended the symposium.

In October 2011, the CSS hosted "The $13^{\text {th }}$ International Congress of Stereology" at Tsinghua University in Beijing. Prof. H. J. G. Gundersen, and the formerly presidents of ISS Prof. B. Pakkenberg, Prof. J. Bertram, Prof. D. Jeulin, the then president of ISS, Prof. J. R. Nyengaard, and all the then vice presidents of ISS and general secretary for the ISS attended the congress. About 200 delegates came from 16 countries. To celebrate the 50 anniversary of the establishment of the ISS, a special commemorate session was arranged at the $13^{\text {th }}$ ICS, in which Professors Dallas Hyde, Jens R. Nyengaard, Dominique Jeulin and Guoquan Liu, successively made commemorative lectures: "ISS 50 Years", "ISS Bioscience 1961-2011", "ISS Materials Science 1961-2011" and "Stereology in China". The lecturers systematically reviewed the development process of stereology in the world and in China (Fig. 3).

With the progress of international exchanges and cooperation in the field of stereology in China, since the 1990s, Chinese scholars have invited more international experts to give lectures and have communications in China. The CSS has more and more invited the leaders and experts of ISS to participate in the academic activities held by the CSS. Professor Nyengaard was invited to participate in the "Chinese Stereology and Image Analysis Conferences" held by the CSS in 2008 and 2014, respectively, and made the invited lectures in both conferences.

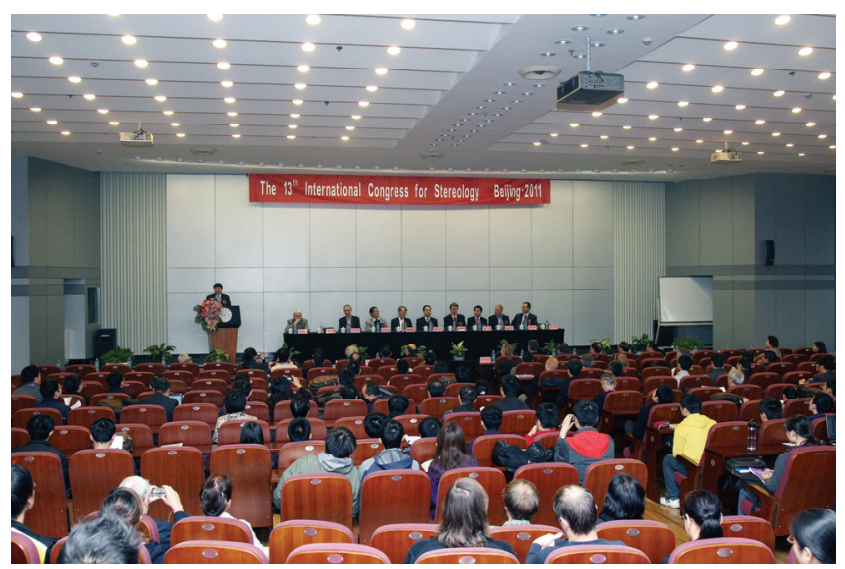

Fig. 3. The $13^{\text {th }}$ International Congress of Stereology, Beijing, 2011.

\section{ESTABLISHMENT OF ACADEMIC COMMUNITY}

The establishment of academic society in the field of stereology is the result of the dissemination, application and development of stereology in China. After six years of preparation, the Scientific and Technological Commission of the People's Republic of China (now the Ministry of Science and Technology of the People's Republic of China) approved to establish the Chinese Society for Stereology (CSS) in June 12, 1987, and the CSS was registered in the Ministry of Civil Affairs of the People's Republic of China. The founding ceremony meeting was held in Beijing Academy of Military Medical Sciences in November 1988. In the meeting, the first session of the CSS council was elected, and Professor Wenqi Zhang, the formerly president of the University of Science and Technology Beijing, was elected as the first CSS president.

When the CSS was initially established, there were more than 200 members and three professional branches. After 30 years of development, 6 professional branches have been set up, which include that of the Image Analysis, the Materials Science, the Biomedicine, the Metallography and Microscopic Analysis, the CT Theory and Application, and the Virtual Reality and Simulation. There are other four working committees, which include the Academic Committee, the Member Working Committee, the Science and Technology Award Review Committee, the Standardization Technical Committee. There are more than 1,500 individual members, 89 council members, 29 standing council members nowadays in the CSS. The CSS Secretariat Office is now based on the Department of Engineering Physics of Tsinghua 
University, Beijing. The CSS is one of the national first-class professional societies under the China Association for Science and Technology, as well as a group member of the ISS.

\section{THE JOURNAL AND WEBSITE OF STEREOLOGY}

Based on the informal journal titled as "stereology communications" founded in 1987, the CSS further founded its official journal in February 1996, titled as "Chinese Journal of Stereology and Image Analysis". Academician and the formerly president of Chinese Academy of Sciences Dr. Jiaxi Lu, Academician of Chinese Academy of Sciences and China Engineering Academy as well as Third World Academy of Sciences (TWAS) Dr. Changxu Shi, Academician of China Engineering Academy Dr. Sichang Jiang, all congratulated on the journal and wrote inscriptions for its first issue. Until the end of 2017, "Chinese Journal of Stereology and Image Analysis" has published a total of 22 volumes, 88 issues and 1375 papers. The journal is divided into the following sections: Image Analysis, Materials Science, Biomedicine, CT Theory and Application, Virtual Reality and Simulation, Experience Exchange, Dynamic and Information, and Review.

In August 1995, the CSS set up its official website (www.tscss.org) to report the activities of the society, membership information, the development of stereology and the related areas.

\section{PROGRESS OF STEREOLOGY DISCIPLINE IN CHINA}

\section{EXAMPLES OF THE STEREOLOGY PROGRESS IN CHINA \\ Stereological definition and 3D CT imaging}

The stereology has its distinguished name, relatively independent knowledge system, explicit object of study, professional societies and academic organizations, etc., that is, the stereology undoubtedly has the basic connotation of an academic discipline. However, as an inter-discipline, the definition of "stereology" has different expression ways in different context or different research fields. The successive presidents of the ISS, the ISS by laws revised 1987-8, the Webster's
Encyclopedic Unabridged Dictionary of the English Language, the Oxford English Dictionary, the American Society for Testing and Materials (ASTM) standards, and the Chinese National Standard (GB/T 18876.12002) literature (Liu, 2001) have made their own definitions of stereology, respectively. At least in China, the different expressions of the stereology definition have directly hindered the academic system construction of stereology. Thus, the CSS organized a wide range of discussions nationwide in China in 2012-2014 under the support of the China Association for Science and Technology, which led to some relatively consistent views, including definitions of stereology, the relations among stereology and CT (Computed Tomography), 3D imaging, 3D reconstruction, and so on.

Although the word "stereology (stereo + logy)" has different definitions, the core content of the definition of stereology is the science that describes quantitative properties of a three-dimensional structure from sections and projections. The experts from the CSS agree that, on the basis of this core content, different branches or different fields of the discipline are allowed to give the expanding definitions of stereology in order to meet their own needs, through such expanding definitions should not deviate from the core definition of stereology, that is, the research purpose of stereology is to obtain the quantitative characteristics and accurate description of the solid structure or three-dimensional (or n-dimensional) geometric structure.

Based on the understanding of the core meaning of the stereology definition, the academic view that the reconstruction of the 3-dimensional CT images from the projection data of the primary ray (1dimension) also belongs to the stereological research domain is accepted by most experts of the CSS. At the same time, the theories and methods of threedimensional reconstruction of sectional or lower dimensional projected images are formally accepted as the organic components of the theory and method system of stereology.

\section{The monographs and publications of stereology and their influence}

During the past 30 years, Chinese scholars published stereological monographs and textbooks in different fields. See Table 1 and Fig. 4. 
Table 1. 1978-2014 stereological monographs edited by Chinese scholars.

\begin{tabular}{|c|c|c|c|}
\hline Editor & Books name & Press & Academic Area \\
\hline Guoyou Qin & Quantitative Metallography & Sichuan Science and & Materials \\
\hline (1987) & & Technology Press & Science \\
\hline $\begin{array}{l}\text { Delin Ren } \\
(1988)\end{array}$ & An Introduction to Integral geometry & $\begin{array}{l}\text { Shanghai Science and } \\
\text { Technology Press }\end{array}$ & $\begin{array}{l}\text { Stereological } \\
\text { Theory }\end{array}$ \\
\hline Yongning $\mathrm{Yu}$ and & Stereology -the Principle and Application of & Metallurgical Industry & Materials \\
\hline Guoquan Liu (1989) & Quantitative analysis about Microstructure* & Press & Science \\
\hline Fusheng Zheng & Three-dimensional Metrology of Cell & China Union Medical & Biomedical \\
\hline (1990) & Morphology & Univers & Science \\
\hline $\begin{array}{l}\text { Hong Shen and } \\
\text { Zhongying Shen } \\
\text { (1991) }\end{array}$ & Practical Technology of Biology Stereology & $\begin{array}{l}\text { Zhongshan University } \\
\text { Press }\end{array}$ & $\begin{array}{l}\text { Biomedical } \\
\text { Science }\end{array}$ \\
\hline $\begin{array}{l}\text { Genxing Xu } \\
\text { (1994) }\end{array}$ & Quantitative Cytology and Cytochemistry & $\begin{array}{l}\text { Jilin Science and } \\
\text { Technology Press }\end{array}$ & $\begin{array}{l}\text { Biomedical } \\
\text { Science }\end{array}$ \\
\hline $\begin{array}{l}\text { Minlun Zhao, et al. } \\
\text { (1996) }\end{array}$ & $\begin{array}{l}\text { Stereology and Image Analysis Research } \\
\text { Progress }\end{array}$ & $\begin{array}{l}\text { Metallurgical Industry } \\
\text { Press }\end{array}$ & $\begin{array}{l}\text { Materials } \\
\text { Science }\end{array}$ \\
\hline Ping Yang & The Technology and Application of Electronic & Metallurgical Industry & Materials \\
\hline$(2007)$ & $\begin{array}{l}\text { Backscatter Diffraction Technology and Its } \\
\text { Application }\end{array}$ & Press & Science \\
\hline $\begin{array}{l}\text { Zhengwei Yang } \\
\text { (2012) }\end{array}$ & $\begin{array}{l}\text { The Basic Tools for Quantitative Morphology } \\
\text { Study of Biological Tissue }\end{array}$ & Science Press & $\begin{array}{l}\text { Biomedical } \\
\text { Science }\end{array}$ \\
\hline CSS (2014) & $\begin{array}{l}\text { 2012-2013 Stereology Discipline Development } \\
\text { Report }\end{array}$ & $\begin{array}{l}\text { tChina Science and } \\
\text { Technology Press }\end{array}$ & Miscellaneous \\
\hline
\end{tabular}

*This monograph won outstanding Science and Technology Book Award of Metallurgical Ministry in 1990.

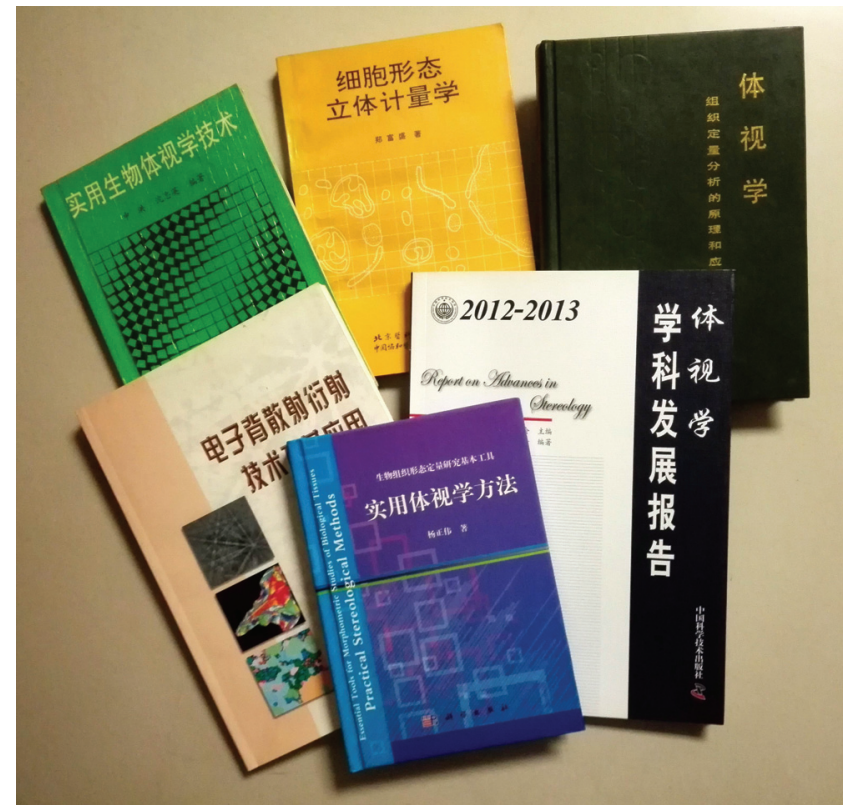

Fig. 4. Some stereological monographs written by Chinese scholars.

These publications and citations of Chinese stereological literature reflect the development and influence of stereology discipline in China over the past many decades. According to the analysis of CNKI literature, the results show that there was no Chinese literature related to "stereology" before 1976, and since
1976, the numbers of literature related to "stereology" were gradually increased. By the end of 2017, there were 1,744 Chinese literature related to stereology (Biomedical Science: 1,019; Pharmacy: 138; Materials Science: 136; Stereology Science: 72; Geological Science: 9; Others: 370 ), and 845 articles were cited. The number of citations was 5,005. Here the numbers of stereology-related literature may be much underestimated, due to the fact that a large number of stereology-related literature are not directly using the word "stereology" itself, but using other stereologyrelated expressions.

\section{Classification of stereological literature}

The numbers of stereological literature have been gradually increased, and the problem of classification of literature also gradually emerges. There was no category of "stereology" in Chinese Book Classification before 2010. In 2008, the experts in the CSS and the experts in Chinese Book Classification discussed and exchanged ideas for many times, and finally reached a consensus that the literature related to the theories and methods of stereology would be classified into the "Natural Science Methodology" in Chinese Book Classification System. In September of 2010, "Chinese Book Classification (fifth edition)" added "stereology" classification and keywords, since then stereological 
literature in the library had corresponding Chinese Book Classification Code.

\section{The establishment of the standards in stereological field}

Quantitative metallography is a branch of the applications of stereology in metal materials. The widely applications of stereology and image analysis equipment are of important value and impact for the development and implementation of metallographic standards. The Chinese stereology experts of materials science drafted out a set of China national standards of materials stereology which were approved and released by General Administration of Quality Supervision, Inspection and Quarantine of China in 2002, 2006, and 2008 respectively: Standard practice for determining the metallographic constituent and inclusion content of steels and other metals by automatic image analysis - Part 1: Determining the inclusion or second-phase constituent content of steels and other metals by automatic image analyses and stereology (GB/T18876.1-2002); Part 2: Determining the inclusion ratings of steels by automatic image analysis and stereology (GB/T 18876.2-2006): Part 3: Determining the carbides rating in steels by automatic image analysis and stereology (GB/T 18876.3-2008). In China, there also are many other national standards focus on or closely related with stereology (in which it is not necessarily containing the word "stereology"), such as GB/T 15749-2008: "Measuring method in quantitative metallography" (formerly GB/T 15749-1995: Manual measuring method in quantitative metallography); GB/T 6394-2017: "Determination of estimating the average grain size of metal"; and so on.

The fields of materials, industrial $\mathrm{CT}$ and biomedical fields need to improve and develop the relevant standards based on the stereological theories and methods. In September 2016, the fourth council meeting of the $6^{\text {th }}$ Council of the CSS was held. In the meeting, the members of the council voted to establish the Standardization Technical Committee of the CSS and adopted the "Statute of the Standardization Technical Committee of Chinese Society for Stereology (Trial)", which laid the foundation for the development of community standards in the field of stereology.

\section{RESEARCH TEAMS IN THE FIELD OF STEREOLOGY}

After 40 years of development, there are nearly 40 research teams in the application fields of stereology in China, which have formed a certain scale. These teams become the mainstay of the stereological research and application research in China. These research teams mainly concentrated in universities, research institutes, enterprises and medical institutions and distributed in the biomedical field, materials field, image analysis field, CT theory and application field and simulation and virtual reality field.

\section{ACADEMIC EXCHANGES AND SCIENCE ACTIVITIES OF STEREOLOGY}

After the founding of the CSS, regular academic activities have been held. "The Chinese Stereology and Image Analysis Conference" is held every two years and until the end of the year 2017, 15 sessions have been held. "The National Digital Radiography and CT New Technology Seminar" is held every year and 13 sessions have been held. "The National Joint Conference of Biomedical Stereology, PLA Military Pathology, and Military Quantitative Pathology" is held every two years, and 10 sessions have been jointly held. "The National Conference of Materials Science and Image Technology" is held every three years, and 10 sessions have been held. "The National Annual Conference on Metallography and Microanalysis" is held every two years, and 15 sessions have been held. "The National Signal and Information Processing Joint Academic Conference" is held every year together with other societies, and 15 sessions have been held. "The Chinese and American Seminar of Stereology and Image Analysis" is held every five years, and 4 sessions have been held.

In March 2009, the then vice presidents of the CSS, Professor Guoquan Liu and Professor Yong Tang, participated in the online interview program "the Presidents Talking about Professional Societies" organized by one of the largest portal sites in China the People's Network, and popularized the basic knowledge of stereology for the broad masses of Chinese Internet users. In 2009, the CSS organized stereological experts to record a set of 70 minute video titled "Image Analysis and Stereology", "Materials Stereology" and "Biomedical Stereology" respectively, and made a 18-minute animation named "Pictorial Stereology". All these videos and animations have been open to public on the internet for free (Fig. 5).

In 2011, a series of wall charts used to popularize the stereological knowledge were designed and prepared by the CSS experts, and distributed to Chinese universities and other units. The 9 wall charts included the introduction of stereology, biostereology, materials stereology, stereology-interdiscipline and the rela- 
tionship between stereology and the life of common persons.

In addition, the CSS also popularizes stereology knowledge through holding the stereological knowledge competition and other activities.

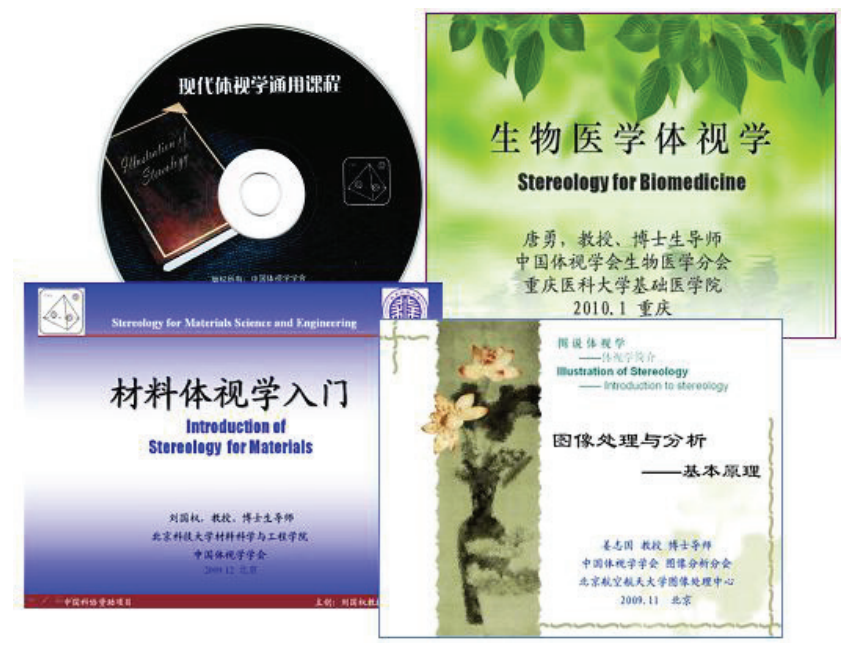

Fig. 5. Basic stereology video course recorded by Chinese stereologists.

\section{ESTABLISHMENT OF THE SCIENCE AND TECHNOLOGY AWARD AND YOUTH AWARD OF CSS}

In 2004, the Science and Technology Award Office of the Ministry of Science and Technology of China approved the CSS to establish the Science and Technology Awards in the field of stereology. The award includes Natural Science Award, Technology Invention Award, Science and Technology Progress Award, Popular Science and Education Award of Stereology. The award is appraised and elected every two years.

In order to promote the growth of young scientific and technological talents in the field of stereology, the CSS has set up the "Science and Technology Award for Youth of the Chinese Society for Stereology" in 2015, and the award is given to the individuals who have made outstanding achievements in the stereology and related fields. In each time, the award is given to less than 6 individuals with the age of no more than 40 years old, and the award is appraised and elected every two years. In 2016, 6 individuals won the award.

\section{CHARACTERISTICS OF STEREOLOGY DISCIPLINE DEVELOPMENT IN CHINA}

\section{THE STEREOLOGY IN CHINA IS DEVELOPED FAST AND APPLIED WIDELY}

As a discipline, the birth and development of modern stereology is inseparable from the modern information technology revolution. The term "stereology" was coined in the early 1960s, but the stereology was systematically introduced into China in the mid1970s. After more than ten years, the CSS set up the mechanism for the stereological personnel education and training, research teams, academic communities and academic journal. The rapid spread and extensive application of stereological knowledge in China has benefited from the rapid development of China's social economy and the extensive application of information technology, and the fundamental driving force lies in social needs. The applications of stereology in China cover almost all areas involving both macro and micro 3-dimensional structures.

\section{REMARKABLE ACHIEVEMENTS OF APPLICATION RESEARCH}

CSS organically links image analysis, materials science, biomedicine, CT theory and application together, which have effectively promoted the rapid development of various disciplines.

In the combination of image analysis and stereological methods, Chinese scholars have developed a large amount of accurate image segmentation methods suitable for image analysis in medical field and materials field, as well as theoretical methods for automatic image recognition and classification, and Chinese scholars have also made some progress in molecular imaging research field, medical image analysis and auxiliary diagnosis field and threedimensional modeling research field.

In the field of materials stereology, in recent years, the obvious progress has been made in various aspects, which include three-dimensional reconstruction of tissue structure and direct observation of expression research, organization morphology and evolutio- 
nary dynamics of numerical calculation, stereology and the seamless coupling of three-dimensional simulation of organizational evolution materials microstructure and the orientation imaging of crystal including Electron Back Scatter Diffraction (EBSD), threedimensional quantification of brain boundary character distribution (GBCD).

In the field of biomedicine, the relevant methods of biomedical stereology are used by almost all disciplines in basic medicine, and especially the application of image analysis technology is much wider. The great progress has been made in the nervous system, reproductive system, dermatology, radiation pathology, etc.

$\mathrm{X}$-ray CT imaging can be attributed to the problem of reconstructing 3D CT images from the projection data along the rays. Chinese scholars have made great progress in basic research such as CT data preprocessing, image reconstruction, image application and so on. Larger breakthrough has been made in the industrial CT development, security CT development, micro-CT development and so on.

In summary, as country with the world's largest population and the second largest economy, China has great potential to develop, promote and apply the stereology and the related technologies. Chinese science and technology workers are willing to continue to work together with the colleagues of the International Society for Stereology and Image Analysis for the further development and applications of stereology and related disciplines.

\section{ACKNOWLEDGEMENT}

Many people have directly and indirectly made invaluable contributions to this article. Some data in this article are cited from the Discipline Development Report Project funded by China Association for Science and Technology in 2012 (2012XSJLW05). Professors Dewen Wang, Rongchun Zhao, Ruiyun Peng, Yue Zhang Rusong Meng and Xiaoyan Song provided valuable original data to the project. We would like to express our appreciation to all the professors who made valuable contributions to the project. At the same time, we are also grateful to Ms. Keyin Liu, the Deputy Secretary-General of CSS, who gave instructive suggestions and valuable comments on the writing of this article.

\section{REFERENCES}

Chinese Society for Stereology (2014). 2012-2013 report on advances in stereology. Beijing: China Science and Technology Press.
Qiling L (1990). Quantitative microscopy and its potential application in cement and concrete science. Journal of Shanghai Institute of Building Materials 4:333-8.

Guoquan L (1992). Recent developments in applying stereology to materials science. Acta Stereol Suppl I: 677-88.

Guoquan L (2001). On the definition, application and methodology components of stereology. Chinese Journal of Stereology and Image Analysis 1:1-5, 12.

Jian Q, Zongyuan M, Quansheng S, et al. (1984). Analyze the possibility of sedimentary facies by image recognition method. Well Logging Technology 2:24-33.

Pellissier GE, Purdy SM (1972). Stereology and Quantitative Metallography. ASTM STP 504, American Society for Testing and Materials, Philadelphia.

Guoyou Q (1987). Quantitative metallography. Sichuan: Sichuan Science and Technology Press.

Delin R (1988). An introduction to integral geometry. Shanghai: Shanghai Science and Technology Press.

Yingchen R, Weijun S, Fengjun M, et al. (1985). The method of combining electron microscope scan-ning analysis with image analysis is used to exactly determine the contents of rare-earth minerals and niobium minerals in ore of a certain iron ore deposit. Acta Petrologica Mineralogica ET Analytica 1:45-51.

Hong S, Zhongying S (1991). Practical Technology of Biostereology. Guangzhou: Sun Tat-sen University Press.

Underwood EE (1970). Quantitative Stereology. Massachusetts, Reading: Addison-Wesley.

Shiqi W (1959). The $\mathrm{Zu}$ Ye principle and its application. Journal of East China Normal University (Natural Science) 2:71-90.

Jiajin W, Weizhang F (1980). A biological image input device for computer. Bulletin of the Academy of Military Medical Sciences 3:309-16.

Genxing X (1994). Quantitative Cytology and Cytochemistry. Jilin: Jilin Science \& Technology Press.

Ping J (2007). The technology and application of electronic backscatter diffraction technology and its application. Beijing: Metallurgical Industry Press.

Zhengwei Y (2012). Practical stereological methods: Essential tools for morphometric studies of biological tissues. Beijing: Science Press.

Zhengwei Y, Chenghu C, Guoquan L (1990). Some shape factors of planar features and their usage. Journal of North Sichuan Medical College 4:11-5.

Jingxia Y, Shaobin Z, Jie X, et al. (1990). Analysis of giemasa banded chromosomes in cereal by means of computer. Journal of Jiangsu Agricultural College 2:21-7.

Zhiwen Y, Danni H, Xiantong C, et al. (1986). Studies on stereology of the grain growth in PLZT transparent ferroelectric ceramics. Journal of Inorganic Materials 2:97-101.

Yongning Y, Guoquan L (1989). Stereology-principle and application of tissue quantitative analysis. Beijing: Metallurgical Industry Press. 
Jingguo Z (1978). Automatic image analyzer and its application in materials science. Shonghai Steel \& Iron Research 1:46-52.

Yi Z, Lianrong S, Dian W, et al. (1989) Age-related changes of substantia nigra of the rat brain: II . quantitative anaytical study on acetylcholinesterase activity by using image analysis system. Acta Anatomica Sinica 3:286-90.

Minlun Z, Kongqi D, Shu L, et al. (1996). Stereology and Image Analysis Research Progress. Beijing: Metallurgical Industry Press.
Rongchun Z (1996). Progress and prospects of image analysis techniques. Chinese Journal of Stereology and Image Analysis (1-2):102-6.

Fusheng Z (1990). Three-dimensional morphometry of cell morphology. Beijing: Peking Union Medical College Press.

Qihan Z (1989). Application of remote sensing image and gravitic-magnetic data to analyse the distribution characters of the structure magma bodies in the middle part of Ningzhen area. Mineral Resources and Geology 12:46-52. 